\title{
New Zealand labour force participation: the ninety years to 1981
}

\author{
P M Revell* and Peter Brosnan+
}

This paper examines labour force participation in New Zealand from 1891 to 1981. It commences with a brief review of previous work in the area and then draws upon data from the New Zealand Census of Population and Dwellings to investigate participation rates. Age-specific data for Maoris, non-Maoris and Pacific Island Polynesians are analysed and male rates are compared with female rates. The paper concludes by identifying unresolved questions requiring further research.

\section{Introduction}

Aside from wage issues, there is probably no topic pertaining to the New Zealand labour market which attracts as much attention as the subject of activity rates or labour force participation. Our estimate is that there are at least 200 papers or articles which touch on this topic. The concept of an activity rate or labour force participation rate is a simple one, viz the percentage of a population sub-group which is in the labour force'. Since the labour force is defined as those working plus those seeking work, the participation rate concept is frequently taken as a measure of the supply of labour. For example, it is used together with population projections to forecast the supply of labour. It is also used for comparative purposes; such as to estimate the extent to which different population sub-groups participate in economic activity and thus have access to income and economic power.

\section{The participation rate concept}

Like most summary measures, the concept has its shortcomings. As Beneria (1981) states, the concept "reflects the link between the concepts of labour force and national product active labour being defined as that which contributes to the national product plus involuntary inactive or unemployed labour" (p 12). Thus the concept is useful if we wish to measure who is producing goods and services for sale. On the other hand, if we are interested in who is, and who is not, working, it is of little assistance since it frequently renders invisible women, children and the aged, who may perform domestic work in the home but outside the market sector. Other criticisms of the concept are its being limited to regular full time workers and its narrow definition of the unemployed - those seeking work - and therefore the exclusion from the labour force of discouraged workers who would seek work were it likely to be available.

The question of hours worked is particularly important. Since 1945, the Department of Statistics has defined the labour force as persons working (or seeking work) for 20 hours per week or more. ${ }^{2}$ However, detailed figures for the part-time labour force, those working less than 20 hours, have been available only for the last 5 censuses. Prior to 1945, the labour force had been regarded as all persons working irrespective of hours worked. Thus, participation

1 Formally: Participation Rate: PR = Labour Force/population; or for a specific group e.g. persons 15-19 years: PR15-19 = Labour force aged 15-19/Population aged 15-19.

2 From 1986 the definition will change to 30 hours a week.

* Postgraduate student, Victoria University of Wellington

+ Senior Lecturer, Industrial Relations Centre, Victoria University of Wellington 
rate series extending back beyond 1945 are not strictly comparable with the modern definition of 20 hours or more. Nevertheless, this problem should not be overemphasised since the availability of part-time work is a recent phenomenon. To complicate the issue further, the Department of Labour defines full time work as 30 hours per week or more. Thus rates based on Department of Labour data will differ from census data. However, there is only one major study which uses Department of Labour data (Hyman, 1980).

\section{Previous studies}

Despite the large number of articles dealing with participation, their coverage is rather patchy. The most comprehensive study was produced 15 years ago as a doctoral dissertation. Neild (1971) examined trends in participation from 1891 to 1966 by sex, from 1921 to 1966 by rural-urban area and from 1951 to 1966 by ethnic origin (Maori and non-Maori). Two factors lessen the utility of Neild's study. First, and most obviously, it does not cover the 15 years to the last census. Secondly, many of his data appear questionable in that we have been unable to replicate his calculations for 1891-1956. The latter problem also applies to a more recent thesis which examined trends in female participation from 1891 to 1976 . This study by Mawer (1982) draws on unpublished material by B J G Thompson for the period 1891 to 1936 and her estimates differ from the rates computed from official data.

The remaining major studies which use census data (Carmichael, 1975; Hyman, 1978a, 1978b, 1979, 1980; Moir, 1976; Penhale, 1980a, 1980b; Ross, 1977) are also of women's participation only, as are ones drawing on other data sources (Hyman, 1980) and on special surveys (Shipley, 1981; Society for Research on Women, 1976, 1981: Thomas, 1975). The latter studies concentrate on specific areas and most of the census studies analyse women's participation according to geographic area but Penhale's (1980b) study is broader than the others as it examines the participation experience of Maori and Pacific Island Polynesian women and looks at participation in the part-time labour force. Hyman's (1980) study involving Department of Labour data is the only other national study which examines participation in the part-time labour force in any detail.

The gaps in literature are thus considerable. There is no study which examines the changing participation propensity for either sex over the 90 years 1891 to 1981 . The analysis of Maori participation has been limited to a few periods, despite there being Maori data since 1926 and the analysis of participation in the part-time labour force is limited to females. We aim in this paper to fill those gaps. First we review the trend in full-time participation rates over 1891-1981 and for Maoris over 1926-1981. We then examine the age specific trends for each sex over the same period. Attention is then focussed on the participation data by major races from the 1981 census. Finally, we investigate participation in the part-time (less than 20 hours) labour force by the major races.

\section{Total full-time participation rates: 1891-1981}

Figure 1 illustrates changes in total full-time participation rates for non-Maori males and females over the period 1891-1981 and Maori males and females over the period 1926-1981. Unfortunately, the data for non-Maoris is not continuous due to changes in the age grouping of the published data.

\section{Females}

If we examine non-Maori female labour force participation, 2 points are immediately obvious. First, participation has been increasing, almost continuously, since 1891. There are some reversals of this trend, however. Female participation was lower in 1906 than it had been at the previous census; the same is true of the 1916, 1926 and 1951 censuses. The 1916 observation is interesting since it occurred during the middle of World War One and it might have been expected that a larger proportion of women would be actively involved in the labour force, as replacements for men who had left for war. Nevertheless, we should note that the 1916 census was taken in October, one month before the Government introduced conscription. A later census could have yielded different results. 
Labour force participation

79

Figure 1: Total full time participation rates: 1891-1981

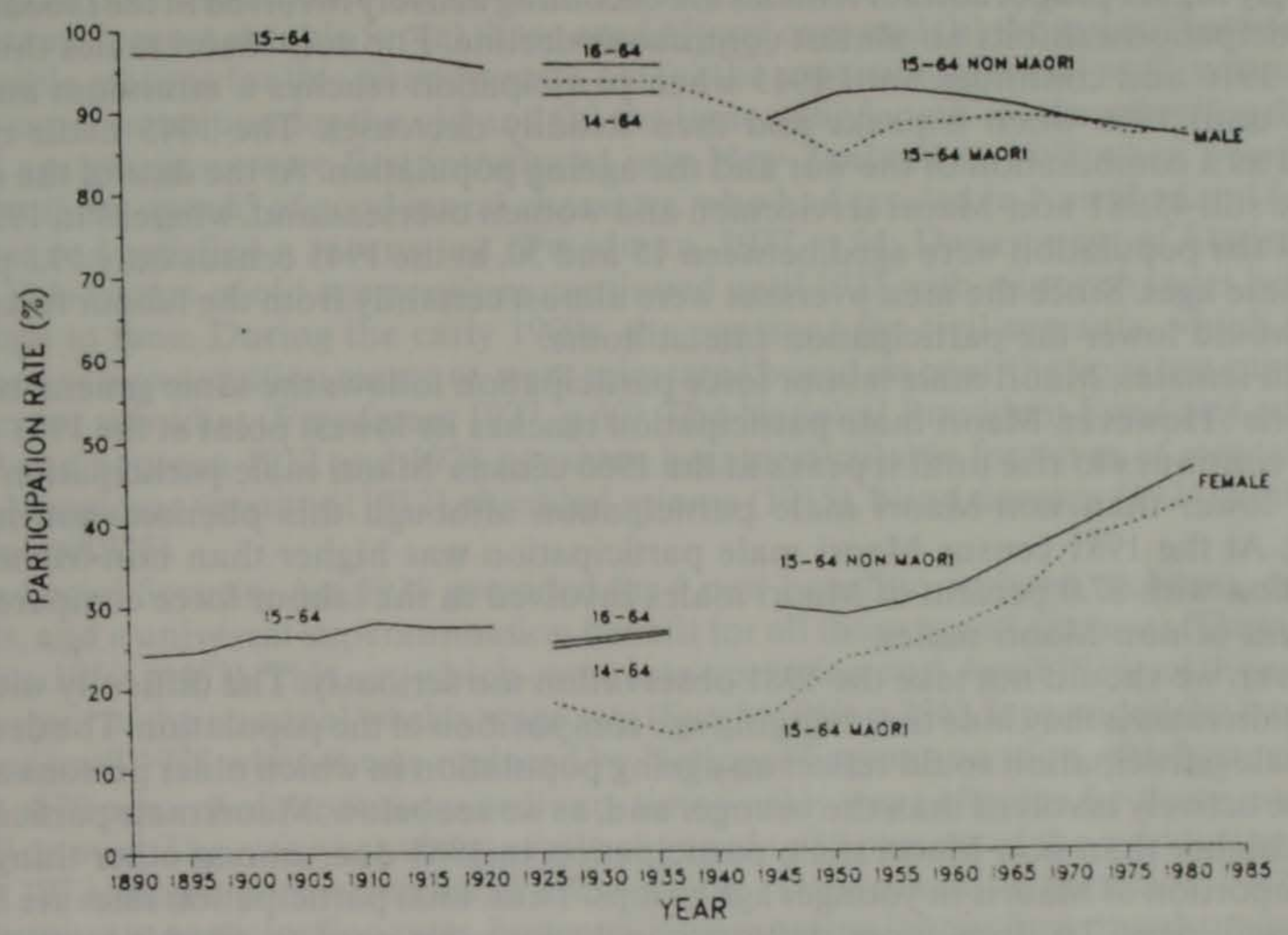

As for the drop over 1945-1951, the 1945 census was taken at the end of World War Two and represented a temporary peaking in female labour force participation. Commentators seeking to explain this phenomenon argue that women replaced the male labour force during the war and were both pushed out of their jobs and left voluntarily to marry when men returned (see. for example, Carmichael, 1975, p 82).

Despite the decrease in female non-Maori participation between 1945 and 1951, female labour force involvement has exhibited a steady and rapid rate of increase since 1951. Between 1951 and 1981, non-Maori female participation rates increased by almost two-thirds as against minimal increase between 1921 and 1951 and an increase of a sixth between 1891 and 1921.

It will be noted that Maori female participation has been lower than non-Maori female participation at every census since comparable data first became available. For the 1981 census, non-Maori female labour force participation was 46.1 percent whereas Maori participation stood at 42.3 percent. Two other significant differences are also evident. First, Maori female participation declined markedly between 1926 and 1936. This trend is probably due to the interaction of the depression of the $1930 \mathrm{~s}$ and discrimination and thus the withdrawal of Maori women from the work force (discouraged workers). Unfortunately we cannot gauge the extent of Maori unemployment during the 1930 s since only the non-Maori population had the option of recording themselves as unemployed on their census questionnaires. The second significant difference is that unlike non-Maori females, Maori females' labour force participation was higher at the 1951 census than it had been at the 1945 census. However, Maori female participation was still lower in 1951 than non-Maori participation had been in 1945 or at any census for which participation data had been recorded. It was the post-war Maori rural-urban migration which saw an acceleration in Maori female participation rates. Between 1951 and 1981, the Maori female participation rate increased by four-fifths compared to non-Maori female participation which increased by three-fifths.

Males

If we contrast male participation with female, 2 points are apparent. First, and obviously, male participation has always been much higher than female participation for both Maoris 
and non-Maoris. At the 1981 census, 86.2 percent of non-Maori males were involved in the labour force, compared with 46.1 percent of non-Maori females. Secondly, whereas increasingly higher proportions of females are becoming actively involved in the labour force; male participation exhibits an almost continuousdecline. For non-Maori males this trend begins at 1916 and continues until 1945 when participation reaches a minimum and then increases until 1956 when it peaks and then steadily decreases. The 1945 nadir may be explained as a combination of the war and the ageing population. At the date of the census, there were still 45,381 non-Maori servicemen and women overseas and, whereas in 1936, 26.3 percent of the population were aged between 15 and 30 , at the 1945 census only 19.8 percent were of these ages. Since the men overseas were almost certainly from the labour force, their absence would lower the participation rate at home.

As with females, Maori male labour force participation follows the same general trend as non-Maoris'. However, Maori male participation reaches its lowest point at the 1951 census and then continues to rise until it peaks at the 1966 census. Maori male participation is also generally lower than non-Maori male participation although this phenomenon may be changing. At the 1981 census Maori male participation was higher than non-Maori male participation with 87.0 percent of Maori males involved in the labour force compared with 86.2 percent of non-Maori males.

However, we should not take the 1981 observation too seriously. The difficulty with total participation rates is they hide the changing age composition of the population. The declining level of male participation could reflect an ageing population in which older persons are less likely to be actively involved than the younger and, as we see below, Maori male participation has been higher than non-Maori male participation in 1981 due, among other things, to a higher proportion of Maoris in younger age groups. Thus, total participation rates are limited in their usefulness. To draw more definite conclusions, we need to examine age specific participation rates.

\section{Age specific full-time male participation rates}

\section{Non-Maoris}

Figure 2 illustrates age specific non-Maori male participation rates for 1891 to 1981 . Two

Figure 2: Age specific full time male participation rates non-Maoris: 1891-1981

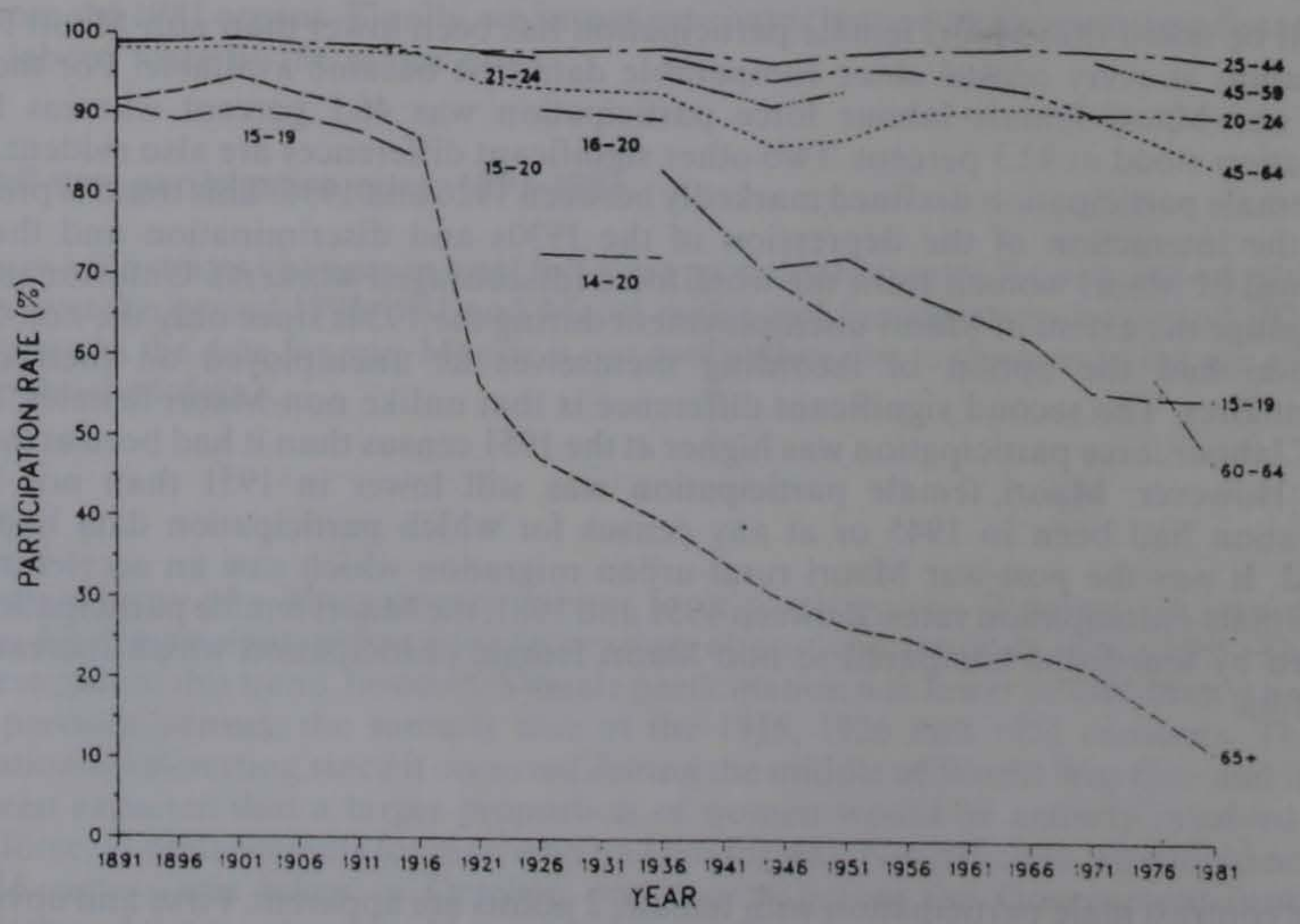


points are immediately obvious. First, labour force involvement has remained relatively constant, around 98 percent, for those aged 25 to 44 . Secondly, we can now see the decline noted in the previous section has been dominated by those aged over 45 and those under 25 . This decline is most notable for (a) those aged 65 and over and (b) those aged between 15 and 19. Possible reasons for this phenomenon are (a) the provision of social welfare benefits and private superannuation for the old and (b) the increasing length of education for the young.

Old age pensions were first introduced into New Zealand in 1898 when provision was made for those over 65 of good moral character, who had resided in New Zealand for at least 25 years, and satisfied a means test (Freedman, 1977. p 54; Department of Statistics, 1900 , p 442). This system of old age pensions continued until 1938 with minor changes being made from time to time. During the early 1900 s, the pensions for civil servants, which had been abolished as a cost-cutting measure, were reinstated based on contributions but supported by government subsidies (Freedman, 1977, p 60). The National Provident Fund was established in 1910 and between 1912 and 1928 pensions became available for wives of mental patients (1912), Maori war veterans (1912), disabled miners (1915), blind persons (1924) and a family allowance (1926).

The Social Security Act 1938 provided for 4 new benefits: orphans, sickness, emergency benefits, and a universal superannuation benefit for all those age 65 and over (Department of Statistics, 1950, p 453). This act, which came into operation on 1 April 1939, set the age benefit at 30 percent of the nominal weekly wage rate (Sutch, 1966, p 236). It provided the basis for age pensions until 1977 when it was replaced by National Superannuation which provided for a benefit of 70 percent of the average ordinary time weekly wage after tax for those married and aged 60 or over. The rate was subsequently changed to 80 percent of the weekly wage from 30 August 1978. Single persons received a lower rate. (Department of Statistics, 1982, p 154).

Returning to participation rates, however, if we examine labour force involvement of those aged 65 and over, it appears the availability of pensions has had little impact on labour force participation. A higher proportion of those aged 65 and over were in the labour force in 1901 than had been in 1896 prior to the introduction of pensions in 1898. Participation for this group did fall between 1936 and 1945 and between 1976 and 1981, however, these decreases are not as marked as the decreases which occurred between 1916 and 1921 and 1921 and 1926 attributable to the change from war to peace and the general economic situation.

The labour force involvement of those aged 65 and over has certainly dramatically declined, but the availability of pensions cannot be the chief explanation. A decline in demand for older workers is as plausible an explanation. We should also note the decrease in the proportion of 60-64 year olds actively involved in the labour force for whom the universal pension has only been available since 1977 . Unfortunately, data for non-Maoris in this age group are not readily available prior to 1936 nor between 1951 and 1976 . Poot and Brosnan's (1982) paper provided participation rates for all males for 1971, 1976 and 1981 and these showed a continuous rate of decline between 1971 and 1981 which lends further weight to the view that participation is not affected by pension availability. Nevertheless, the decrease in participation by the 60-64 group appears to account for most of the declining participation of those aged 45 to 64 and, if we examine the participation levels of those aged $45-59$, we see they have remained reasonably constant between 1936 and 1981 .

The declining participation levels of non-Maori males aged 15 to 19 and, to a lesser extent 20-24 is easier to explain. Schooling was first made compulsory for those aged between 7 and 13 in 1877 . In 1914 the minimum school leaving age was raised to 14 for most pupils (Sutch, 1966, p 269). The age was raised to 15 in 1944. Whereas in 191619.3 percent of the male population aged 15-19 were at school (Department of Statistics, 1916) by 1981, this proportion had risen to 36.8 percent (Department of Statistics, 1982. Thompson, 1985). Increased schooling obviously accounts for the declining participation of those aged 15 to 19 . The increasing number of people undertaking tertiary education largely accounts for the declining level of labour force involvement of those aged between 20 and 24 . For example, the number of people attending full-time at either a technical institute or university, increased by 65.5 percent between 1970 and 1981 (Department of Statistics, 1971, 1982).

\section{Maoris}

Figure 3 illustrates participation levels for Maoris from 1926 to 1981. The data available reveals trends similar to those for non-Maori males. First, Maori males aged 65 and over do 
Figure 3: Age specific male participation rates Maoris: 1926-1981

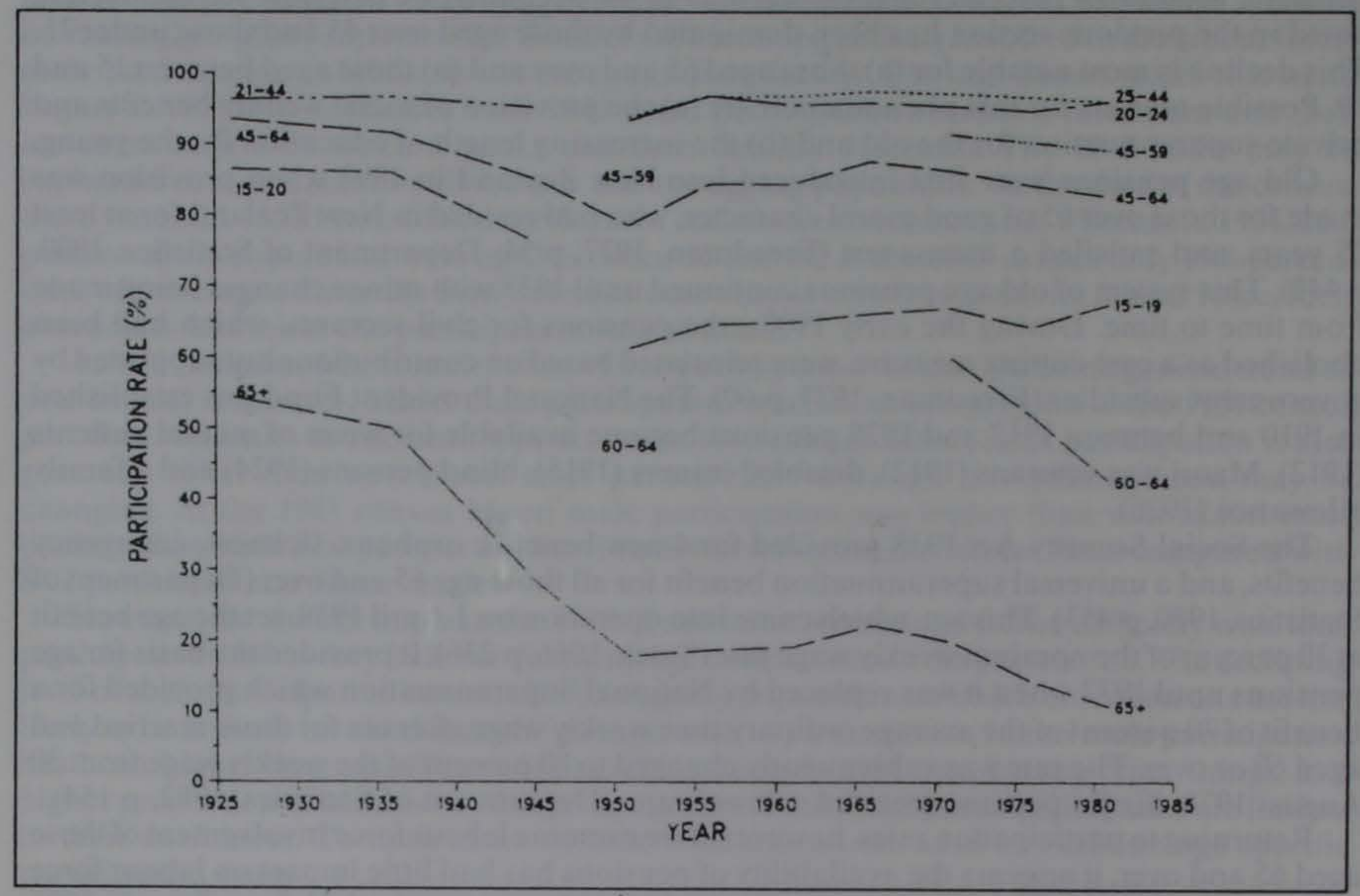

exhibit the same overall decline in participation as non-Maori males. However, participation rates for Maori males in this age group rose between 1951 and 1966. Secondly, like non-Maori males, the participation of those aged between 25 and 44 has remained relatively constant throughout the 1951 to 1981 period. Maori male participation for this age group is slightly lower than non-Maori participation; for Maoris it ranges from 93.9 percent to 97.6 percent whereas for non-Maoris it ranges from 97.5 percent to 98.9 percent. Unlike non-Maoris. Maori males aged 15 to 19 do not exhibit continuously declining participation. Unfortunately it is difficult to draw definite conclusions about trends in this group's labour force involvement due to a change in the age groupings from the 1951 census. Nevertheless, we can contrast Maori and non-Maori male participation from 1951 to 1981. In 1951, 61.2 percent of Maori males aged 15-19 were actively involved compared to 72.5 percent of non-Maori males. Although by 1981 non-Maori participation for this age group had fallen to 55.2 percent. Maori participation had actually risen to 67.4 percent. This difference provides some of the explanation for total Maori male participation being higher than total non-Maori male participation in 1981 observed in Figure 1.

\section{Age specific full-time female participation rates}

\section{Non-Maoris}

Female participation rates, both Maori and non-Maori, exhibit a very different pattern to male participation rates. First let us examine non-Maori full-time female labour force involvement (see Figure 4).

Seven points are immediately obvious: first, non-Maori female participation rates are lower at every age group than non-Maori male rates and have been since 1891 (except for the 15-19 age group, between 1961 and 1966). Second, unlike male participation, activity rates for females have increased between 1891 and 1981 in every age group except for those aged 65 and over. Thirdly, women aged between 15 and 24 have always been more likely to participate than older women. This is in contrast to males, who, in recent years have been more likely to participate when aged between 25 and 59. Fourthly, the decline in the overall participation rate which occurred between 1911 and 1916 involved every age group except the 15 -24 group. Fifthly, the participation of those aged between 20 and 24 increased dramatically between 
Figure 4: Age specific full time female participation rates non Maoris: 1891-1981

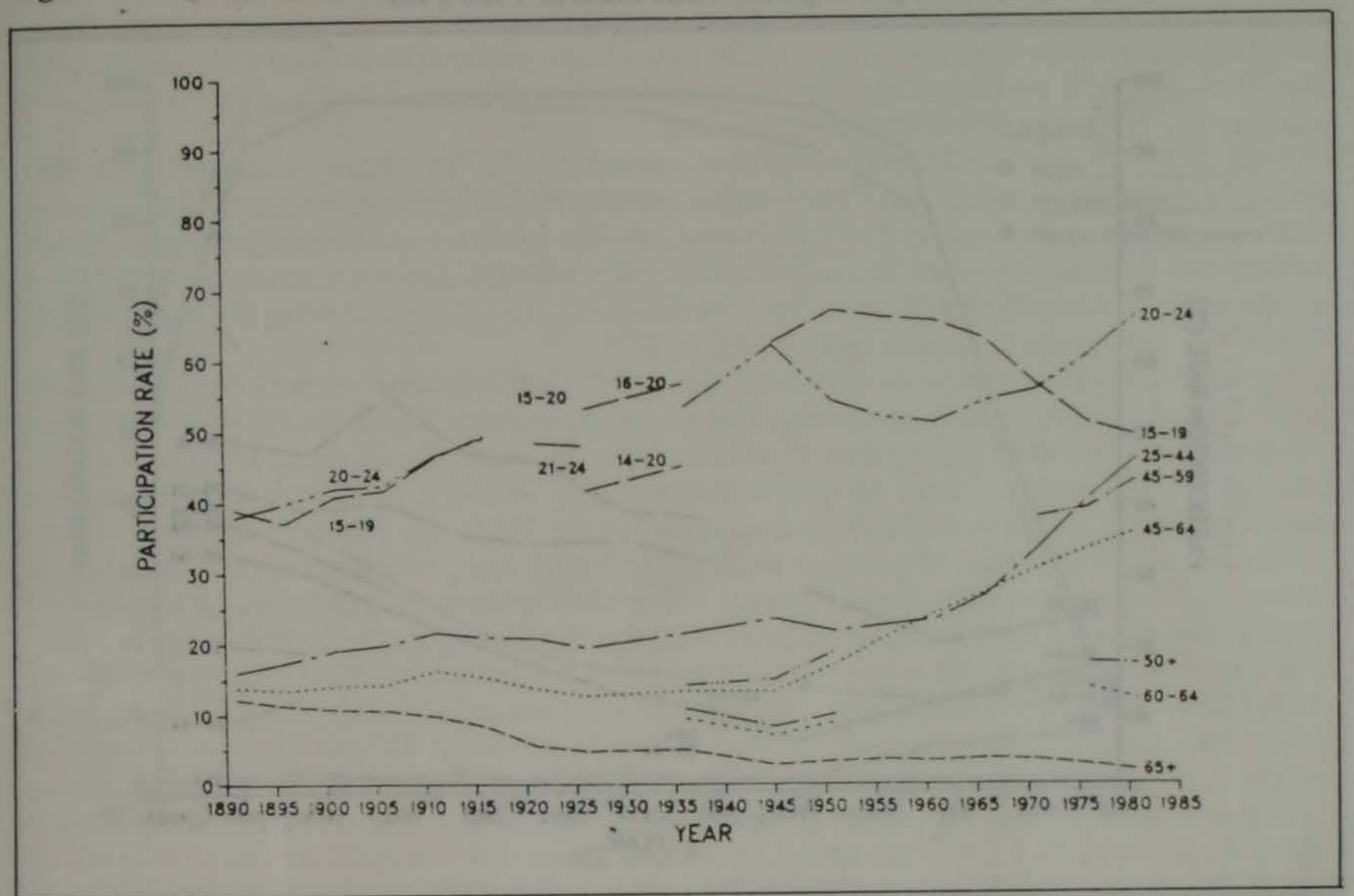

1936 and 1945, possibly as a consequence of an increase in the demand for female labour emanating from wartime conditions. As we noted in Figure 1, overall non-Maori female participation fell between war's end and 1951 . We note there that this decrease was restricted to those aged between 20 and 44 . Sixthly, since 1951, a decreasing proportion of those aged 15 to 19 have been involved in the workforce. We noted above that the trend of falling labour force involvement by the 15-19 age group occurs also for non-Maori males. However the decline begins for males much earlier than 1951. As is the case also for males, non-Maori females are spending a longer period at school. At the time of the 1916 census, 20.1 percent of females aged 15-19 were receiving schooling (Department of Statistics, 1916); by 1981 this proportion had reached 43.1 percent (Department of Statistics, 1982; see Thompson, 1985). Finally, since 1971, participation has increased most rapidly for those aged between 20 and 44 i.e. those whom we would most expect to be married with dependent children.

\section{Maoris}

If we compare non-Maori female participation with the Maori female participation trends in Figure 5, some similarities immediately become evident. As with non-Maoris, Maori female participation rates have increased between 1926 and 1981 for all age groups except those 65 and over. Younger women are also more likely to participate than older women.

However, there are some important differences. First, the decrease in participation which occurred between 1926 and 1936 noted earlier, appears to have occurred for every age group. This may be misleading though as one of the age groups i.e. the group for those aged 21 to 44 , is very broad and may hide totally different trends within that particular age group.

Secondly, whereas the participation of non-Maori females aged 15-19 has been falling since 1951, this trend has not occurred for Maori women. As late as the 1976-81 period, Maori female participation for this age group rose. We noted above, that this also applies to Maori male participation rates. Finally, for the most part, non-Maori female participation rates are higher than the Maori female rates. One of the clearest examples of this occurs in the 1981 data for those in the 20-24 age group; 66.2 percent of non-Maori females in this age group were in the labour force, whereas only 43.8 percent of Maori females were active. We should also note that, as with non-Maoris, Maori female participation rates are lowr at every age group than Maori male rates. 
Figure 5: Age specific female participation rates Maoris: 1926-1981

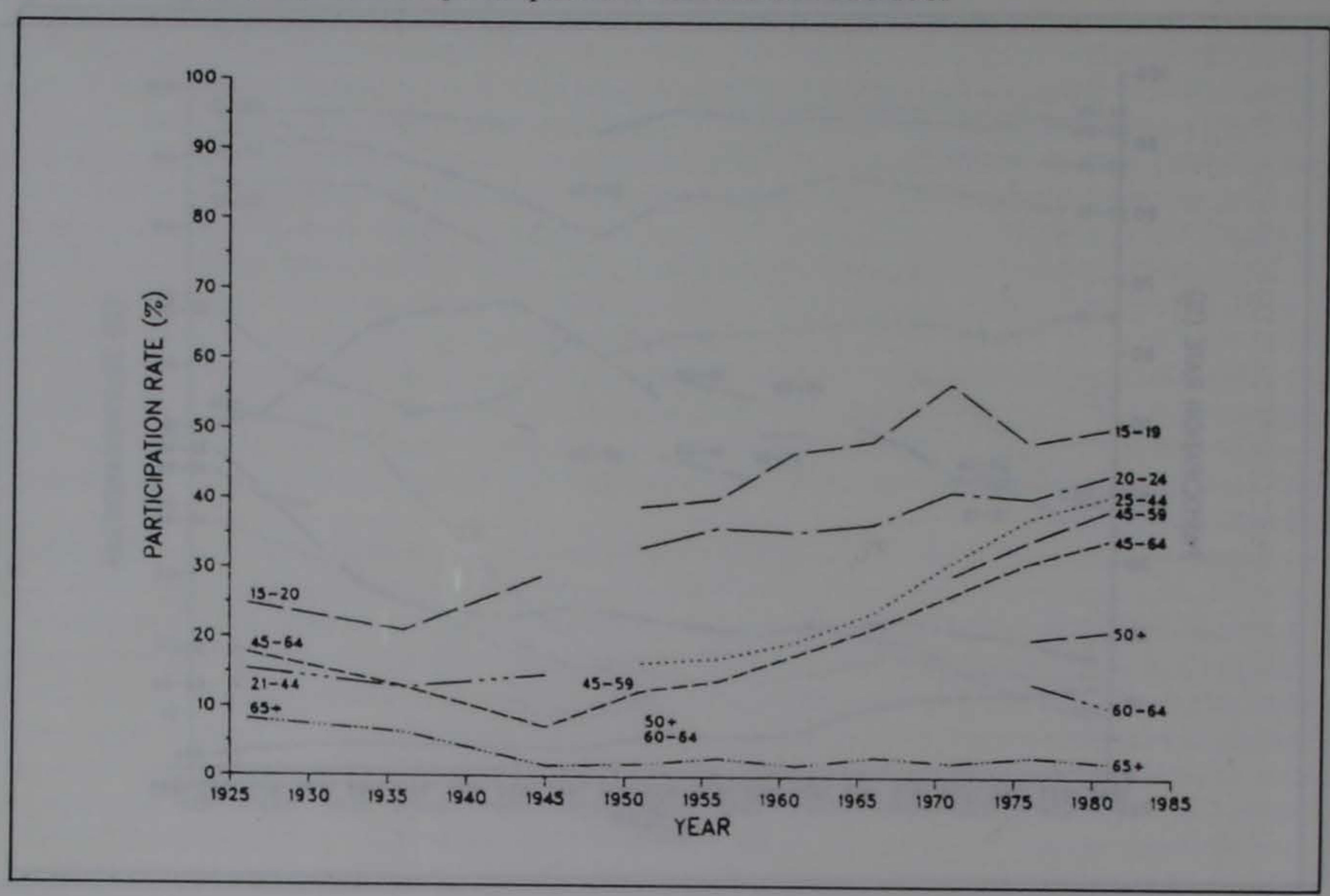

While the data already examined appears to portray clear trends in female labour force participation, it is flawed by the breadth of the age groupings. An age group such as $25-44$ hides potentially interesting trends. Therefore a closer examination of participation rates using narrower age groupings is warranted. This is possible using data for recent censuses. It is to these that we now turn.

\section{Age specific full-time participation rates by major races: 1981}

\section{Males}

In Figure 6, we show participation rates for Pacific Island Polynesian, Maori and nonPolynesian (i.e. those who are neither Maori nor Pacific Island Polynesian) males. Essentially the 3 racial groups follow the same pattern. Between 50 and 70 percent of all males aged 15 to 19 are economically active; participation remains at a high level (over 89 percent) for all 3 races between ages 20 and 54. Finally, participation levels fall rapidly for males of each race after age 55 .

Maori males exhibit a slightly different pattern compared with the other 2 races. Maoris have the highest participation rates at the youngest age groups i.e. 15-19 and 20-24 and Maori activity levels begin to decline earlier than the other races i.e. from the 25-29 age group compared with the 40-44 age group for both non-Polynesians and Pacific Island Polynesians. Finally, between ages 30 and 60 , Maoris have the lowest rates while non-Polynesians have the highest.

The Maori participation rates are influenced significantly, especially at young ages, by the high incarceration rates for Maoris. If we were to compute participation rates for Maoris and non-Maoris with prisoners excluded from the respective populations, we would find that the Maori rate is reduced due to incarcerations by 2 full percentage points for the $15-19$ age group. by 2.9 percent points for the $20-24$ age group and by 1.8 percentage points for the $25-29$ age group. At the 30-39 age group, the difference is reduced to only 0.9 percentage points. This implies that a lower incarceration rate of Maoris would increase the gap between the Maori and non-Maori rates at younger ages and reduce it at the middle ages. 
Labour force participation

85

Figure 6: Age specific full time male participation rates by major races: 1981

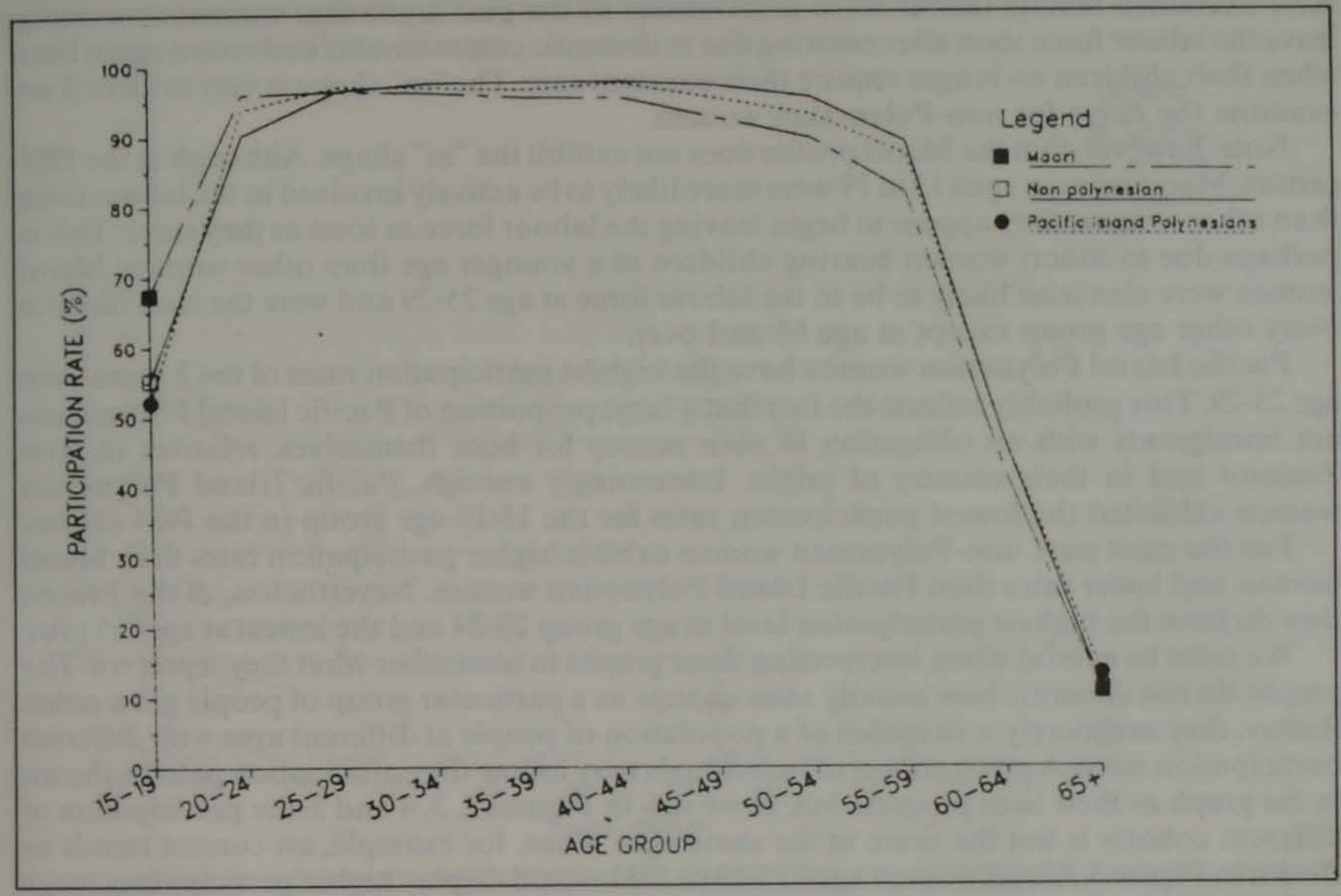

Females

The female participation rates presented in Figure 7 yield a very different looking graph. In contrast to the " $n$ " shaped growth for male participation, the graph for females is " $m$ " shaped. This shape is commonly regarded in the literature as the conventional pattern for female age

Figure 7: Age specific full time female participation rates by major races: 1981

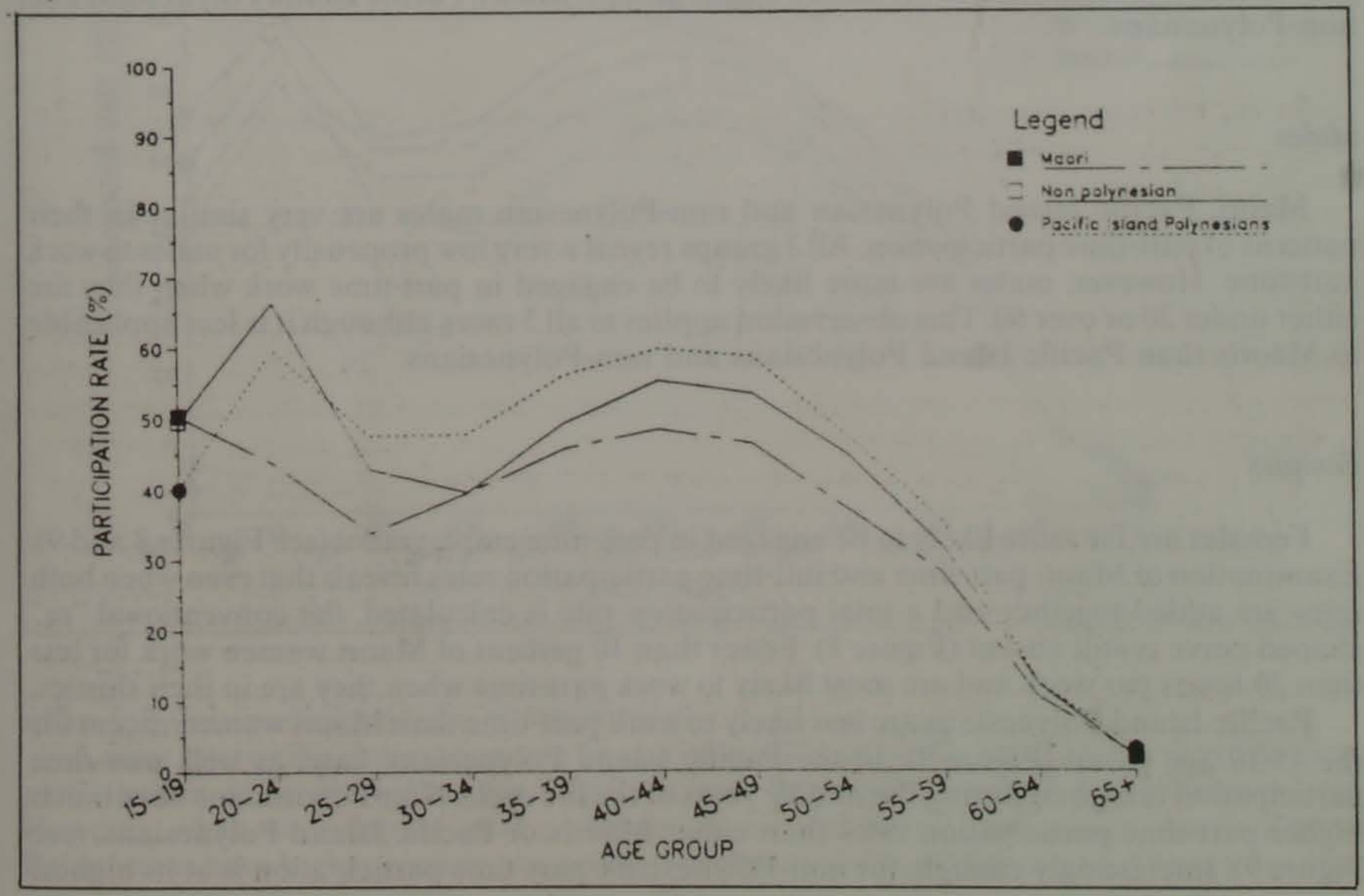


specific participation (see Bowen and Finegan, 1969, p 541-542; Sweet, 1973, p 25). Those who have examined female labour force involvement in the past argue that women commonly leave the labour force soon after entering due to domestic commitments and return again later when their children no longer require their constant care. The " $\mathrm{m}$ " shape is very evident if we examine the curve for non-Polynesian women.

Note, however, that the Maori profile does not exhibit the " $\mathrm{m}$ " shape. Although at the 1981 census, Maori women aged 15 to 19 were more likely to be actively involved in the labour force than other women, they appear to begin leaving the labour force as soon as they enter. This is perhaps due to Maori women bearing children at a younger age than other women. Maori women were also least likely to be in the labour force at age 25-29 and were the least likely at every other age group except at age 65 and over.

Pacific Island Polynesian women have the highest participation rates of the 3 races from age 25-29. This probably reflects the fact that a large proportion of Pacific Island Polynesians are immigrants with an obligation to earn money for both themselves, relatives in New Zealand and in their country of origin. Interestingly enough, Pacific Island Polynesian women exhibited the lowest participation rates for the 15-19 age group in the 1981 census.

For the most part, non-Polynesian women exhibit higher participation rates than Maori women and lower rates than Pacific Island Polynesian women. Nevertheless, of the 3 races, they do have the highest participation level at age group 20-24 and the lowest at ages 65 plus.

We must be careful when interpreting these graphs to remember what they represent. The graphs do not illustrate how activity rates change as a particular group of people grow older. Rather, they are merely a snapshot of a population of people at different ages with different participation rates. A given cohort of individuals may follow the participation pattern shown in the graph as their lives progress but, as we saw in Figures 2, 3,4 and 5, the participation of different cohorts is not the same at the same ages. Thus, for example, on current trends as shown in Figure 5, Maori women aged 15-19 in 1981 would display higher participation at age 20-24 (in 1986) than is depicted for the 20-24 age group in Figure 7.

\section{Part-time participation}

A major deficiency of the analysis so far is that it has been limited to the "economically active" population falling within the census definition of the labour force as persons working 20 hours or more. Labour force participation by those working fewer than 20 hours per week has not been investigated and it is to this we now turn. Our investigation makes use of 1981 census data and is directed at the same 3 ethnic groups: Maori, Pacific Island Polynesians and non-Polynesians.

\section{Males}

Maori, Pacific Island Polynesian and non-Polynesian males are very similar in their patterns of part-time participation. All 3 groups reveal a very low propensity for males to work part-time. However, males are more likely to be engaged in part-time work when they are either under 20 or over 60 . This observation applies to all 3 races although it is less applicable to Maoris than Pacific Island Polynesians and non-Polynesians.

\section{Females}

Females are far more likely to be engaged in part-time employment (see Figures 8 and 9). Examination of Maori part-time and full-time participation rates reveals that even when both rates are added together and a total participation rate is calculated, the conventional " $\mathrm{m}$ " shaped curve is still absent (Figure 8). Fewer than 10 percent of Maori women work for less than 20 hours per week and are most likely to work part-time when they are in their thirties.

Pacific Island Polynesians are less likely to work part-time than Maori women except for the 15-19 age group (Figure 9). In the Pacific Island Polynesians' case, as well, part-time participation is highest during the middle years of the life cycle. Non-Polynesians have much higher part-time participation rates than either Maoris or Pacific Island Polynesians, (see Figure 9). Interestingly enough, for non-Polynesians, part-time participation is at its highest 
Labour force participation

87

Figure 8: Female participation rates: part time and full time Maoris: 1981

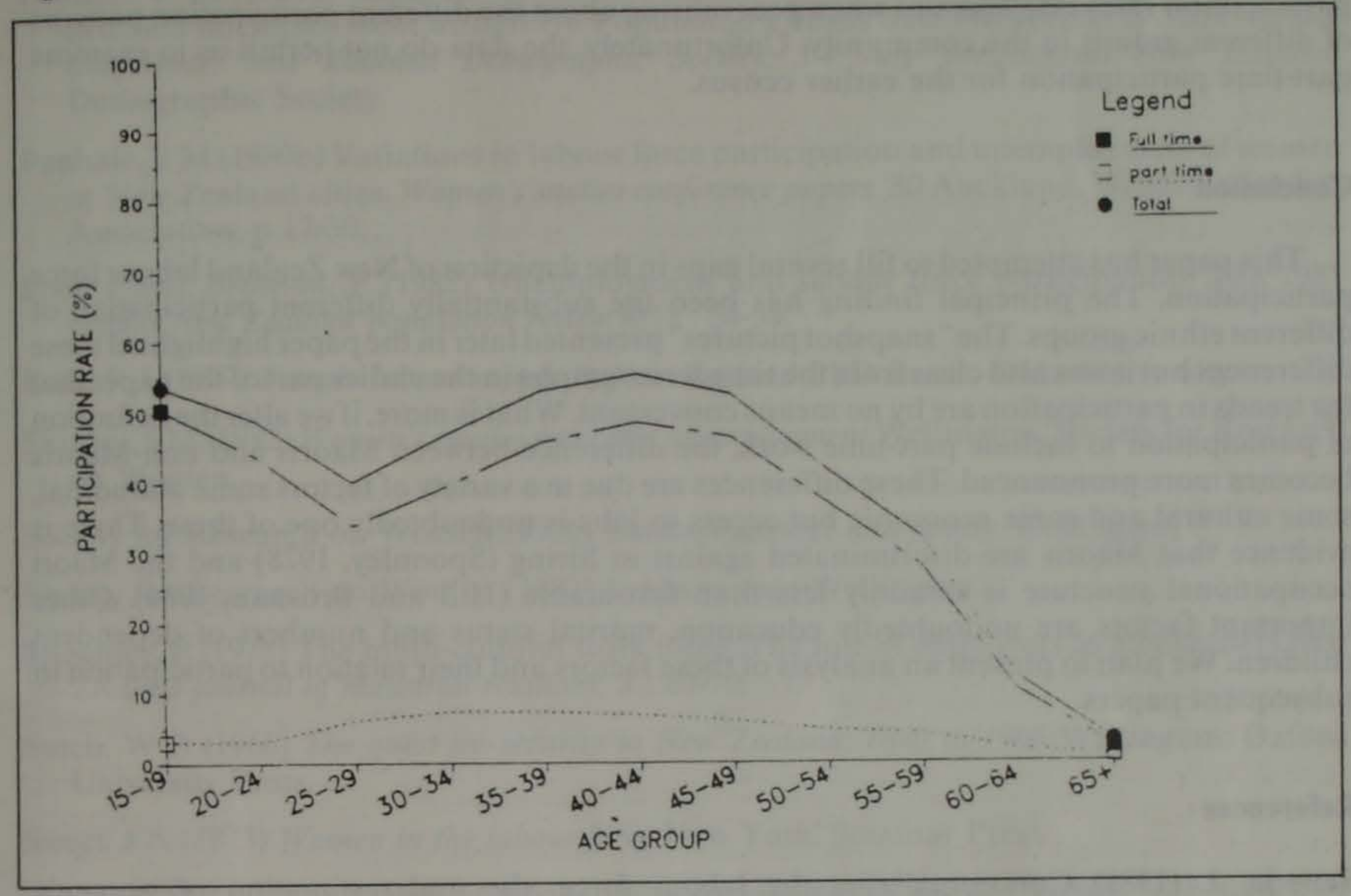

Figure 9: Female participation rates: part time and full time Pacific Island Polynesians and non Polynesians: 1981

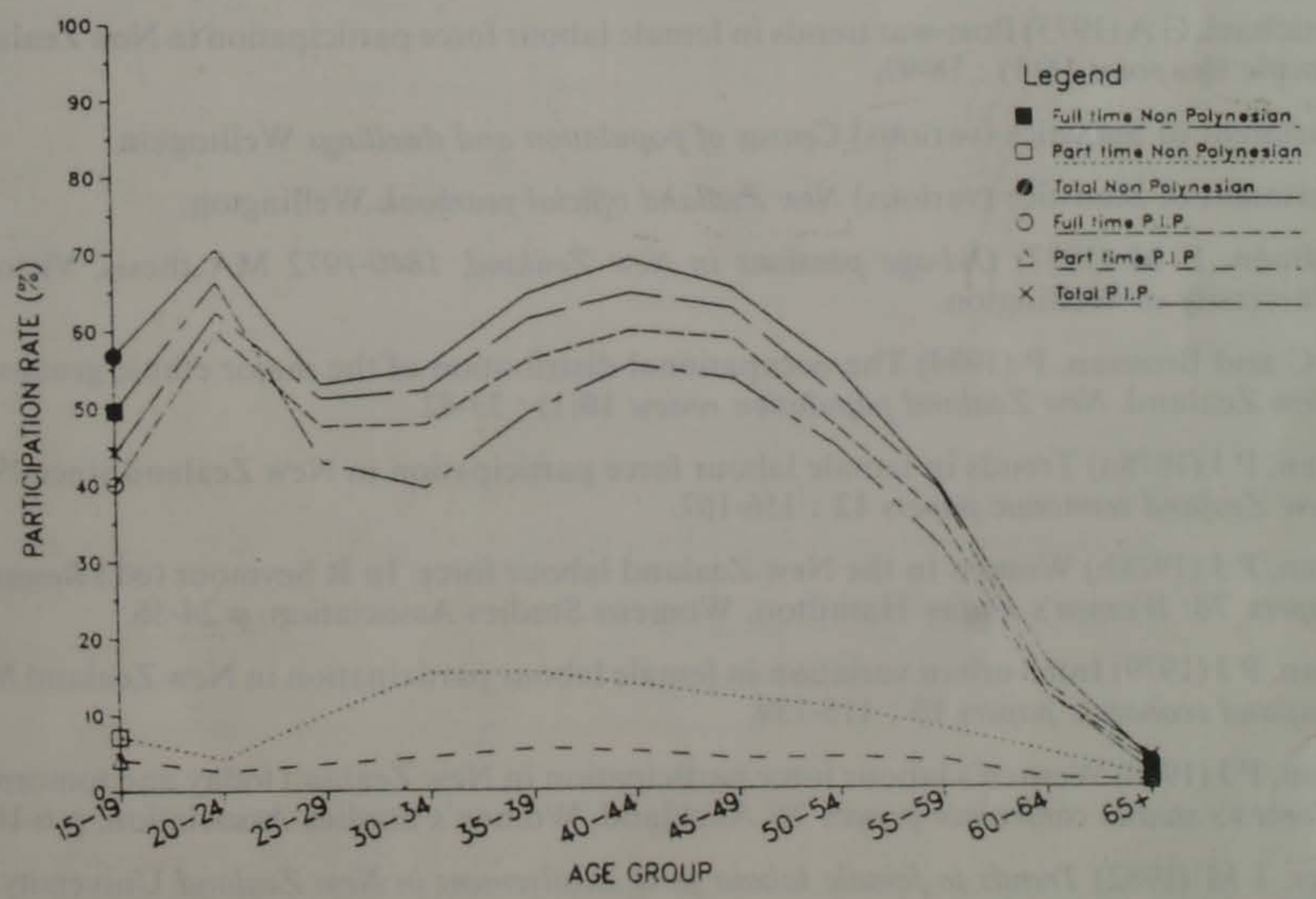

when full-time participation is at a minimum.

A most interesting observation can be made from Figure 9. We noted earlier that full-time participation rates are higher for Pacific Island Polynesians than for non-Polynesians. However, when we compare total participation rates for the 2 race groups, we find nonPolynesians have higher participation rates than Pacific Island Polynesians. Thus our earlier 
conclusion is reversed and we have a graphic example of why it is important to take part-time participation rates into account when generalising about the different participation patterns of different groups in the community. Unfortunately, the data do not permit us to examine part-time participation for the earlier census.

\section{Conclusion}

This paper has attempted to fill several gaps in the depiction of New Zealand labour force participation. The principal finding has been the substantially different participation of different ethnic groups. The "snapshot pictures" presented later in the paper highlighted these differences but it was also clear from the time series graphs in the earlier part of the paper that the trends in participation are by no means convergent. What is more, if we alter the definition of participation to include part-time work, the difference between Maoris and non-Maoris becomes more pronounced. These differences are due to a variety of factors some attitudinal, some cultural and some economic but access to jobs is undoubtedly one of these. There is evidence that Maoris are discriminated against in hiring (Spoonley, 1978) and the Maori occupational structure is certainly less than favourable (Hill and Brosnan, 1984). Other important factors are undoubtedly education, marital status and numbers of dependent children. We plan to present an analysis of these factors and their relation to participation in subsequent papers.

\section{References}

Beneria, L (1981) Conceptualizing the labour force: the underestimation of women's economic activities Journal of development studies 17(13) : 10-28

Bowen, W G and Finigan. T A (1969) The economics of labor force participation Princeton, Princeton University Press.

Carmichael, G A (1975) Post-war trends in female labour force participation in New Zealand Pacific viewpoint 16(1) : 78-97.

Department of Statistics (various) Census of population and dwellings Wellington.

Department of Statistics (various) New Zealand official yearbook Wellington.

Freedman, E M (1977) Old-age pensions in New Zealand, 1840-1972 MA thesis, Victoria University of Wellington.

Hill, C and Brosnan, P (1984) The occupational distribution of the major ethnic groups in New Zealand. New Zealand population review 10(1) : 33-42.

Hyman, P J (1978a) Trends in female labour force participation in New Zealand since 1945

New Zealand economic papers 12 : 156-167.

Hyman, P J (1978b) Women in the New Zealand labour force. In R Seymour (ed.) Research

4 papers '78: Women's studies Hamilton. Womens Studies Association, p 24-36.

Hyman, P J (1979) Inter-urban variation in female labour participation in New Zealand New

- Zealand economic papers 13 : 115-139.

Hyman, P J (1980) Women's labour force participation in New Zealand today and tomorrow Women's studies conference papers '80 Auckland, Women's Studies Association, p 6-16.

Mawer, J M (1982) Trends in female labour force involvement in New Zealand University of Waikato.

Moir, H (1976) Labour force, economic changes and the role of women Wellington. New Zealand Demographic Society (Occasional Paper No 3).

Neild, P G (1971) Labour force participation in New Zealand Victoria University of Wellington. 
Penhale. E M (1980a) Regional differences in female labour force participation and selfdeclared unemployment using 1976 Population Census data Proceedings of Sixth Annual Conference, New Zealand Demographic Society, 3-4 July Wellington. New Zealand Demographic Society.

Penhale. E M (1980b) Variations in labour force participation and unemployment of women in New Zealand cities. Women's studies conference papers '80 Auckland. Women's Studies Association, p 17-30.

Poot, J and Brosnan, P (1982) Unemployment and labour force participation. The 1981 census New Zealand population review $8(1): 24-34$.

Ross, R I (1977) Female labour supply in New Zealand PhD thesis. Duke University

Shipley. S M (1982) Women's employment and unemployment Wellington, Society for Research on Women.

Society for Research on Women (1976) Career, marriage and family Wellington.

Society for Research on Women (1982) Urban women Wellington.

Spoonley, P (1978) The multi-cultural work force: The role of employers as gatekeepers New Zealand journal of industrial relations, 3 : 63-70.

Sutch, W B (1966) The quest for security in New Zealand. 1840 to 1966 Wellington, Oxford University Press.

Sweet. J A (1973) Women in the labour force New York, Seminar Press.

Thomas, M L (1975) Aspects of labour force participation of married women with particular reference to attitudes and work commitment MA thesis, University of Otago.

Thompson, G B (1985) Entrants to the labour force: changes in market conditions and educational qualifications of youth New Zealand journal of industrial relations 10(1): 15-28. 